First publ. in: Archives of Microbiology 189 (2008), 5, pp. 475-482

\title{
Quorum sensing by N-acylhomoserine lactones is not required for Aeromonas hydrophila during growth with organic particles in lake water microcosms
}

\author{
Katharina Styp von Rekowski, Melanie Hempel, Bodo Philipp
}

\begin{abstract}
It was investigated whether quorum sensing (QS) mediated by $N$-acylhomoserine lactones (AHLs) was important for heterotrophic bacteria from the littoral zone of the oligotrophic Lake Constance for growth with organic particles. More than 900 colonies from lake water microcosms with artificial organic aggregates consisting of autoclaved unicellular algae embedded in agarose beads were screened for AHL-production. AHL-producing bacteria of the genus Aeromonas enriched in the microcosms but AHLs could not be detected in any microcosm. To test for a potential function of AHL-mediated QS, growth experiments with the wild type and an AHL-deficient mutant of Aeromonas hydrophila in lake water microcosms were performed. Growth of both strains did not differ in single cultures and showed no mutual influence in co-cultures. In cocultures with a competitor bacterium belonging to the Cytophaga-Flavobacterium group, growth of both $A$. hydrophila strains was reduced while growth of the competitor bacterium was not affected. Exogenous AHL-addition did not influence growth of the Aeromonas strains in any microcosm experiment. These results showed that AHL-mediated QS was not required for A. hydrophila during colonization and degradation of organic particles in lake water microcosms, suggesting that cell-cell signalling of heterotrophic bacteria in oligotrophic waters relies on novel signal molecules.
\end{abstract}

Communicated by Jörg Overmann.

K. Styp von Rekowski · M. Hempel · B. Philipp ( $\square)$

Fachbereich Biologie, Mikrobielle Ökologie,

Universität Konstanz, Fach M654,

78457 Konstanz, Germany

e-mail: bodo.philipp@uni-konstanz.de
Keywords Aeromonas $\cdot$ Biofilm $\cdot N$-Acylhomoserine lactones · Oligotrophic lakes · Quorum sensing
Abbreviations
AHL $\quad N$-Acylhomoserine lactone
CFU Colony forming unit
DOM Dissolved organic matter
QS Quorum sensing
TCC Total cell count

\section{Introduction}

Heterotrophic bacteria contribute significantly to the degradation of organic detritus particles such as aggregates of decaying phyto- or zooplankton (Azam et al. 1993; Simon et al. 2002; Pernthaler and Amann 2005). After initial attachment, bacteria form biofilms to establish a stable association with organic particles. For the degradation of polymers within organic particles, bacteria release extracellular hydrolytic enzymes. In the course of polymer degradation, the respective oligo- and monomers partly diffuse into the surrounding water and create plumes of dissolved organic matter (DOM) serving as nutrients for suspended heterotrophic bacteria (Azam and Long 2001; Kiørboe and Jackson 2001). In oligotrophic waters like Lake Constance where the concentration of DOM is low $\left[<1 \mathrm{mg} \mathrm{Cl}^{-1}\right.$ (Hanisch et al. 1996)], organic particles represent patches of increased metabolic activity of heterotrophic bacteria (Simon et al. 2002).

It has been demonstrated that various cell-cell interactions of heterotrophic bacteria occur at organic particles (Simon et al. 2002; Grossart et al. 2003). Those can be cooperative interactions, such as biofilm formation or sharing extracellular enzymes and their degradation products, 
as well as antagonistic interactions, such as production of inhibitory substances (Long et al. 2005). The release of enzymes and secondary metabolites in a highly diffusive environment will be only rewarding at high cell densities. Therefore, these processes are often controlled by cell-density-dependent regulation of gene expression which is mediated by diffusible signal molecules whose concentration correlates with the population density. This process is termed quorum sensing $(\mathrm{QS})$ (for recent reviews see Waters and Bassler 2005; Keller and Surette 2006). In many aquatic Gram-negative bacteria, QS is mediated by $\mathrm{N}$-acylhomoserine lactones (AHLs). AHL-mediated QS is being intensively studied with host-associated bacteria in the context of pathogenicity and symbiosis while possible functions of this process for free-living bacteria in their natural environments have received less attention (Manefield and Turner 2002; Chhabra et al. 2005; Keller and Surette 2006).

The aforementioned bacterial interactions required for detritus utilization render organic particles a paradigmatic setting for QS. Therefore, we hypothesize that AHL-mediated QS has an important function for heterotrophic bacteria from the water column for growth with organic particles. Several observations support this hypothesis. AHL-producing bacteria have been isolated from marine snow (Gram et al. 2002) and AHLs have been detected in aquatic biofilms (McLean et al. 1997). Including AHLs into media for enrichment cultures enhanced the cultivation efficiency for marine (Bruns et al. 2002) and freshwater bacteria (Bussmann et al. 2001). Interestingly, AHL-producing biofilms attract zoospores of green algae (Joint et al. 2002; Tait et al. 2005). While these studies suggest an important function for AHL-mediated QS in aquatic biofilms, a systematic study to prove this function for aquatic heterotrophic bacteria under natural conditions is, to our knowledge, still lacking. To investigate our hypothesis with bacteria from the water column of the littoral zone of Lake Constance we set up enrichment cultures with lake water samples exposed to organic particles in microcosm experiments. If our hypothesis is correct we expect that AHL-producing bacteria enrich at and in vicinity to organic particles and AHLs can be detected. As methodical prerequisites for this study, we had to develop an appropriate microcosm model system for simulating the colonization of organic particles in the littoral zone and to establish a method for a broad screening for AHL-producing bacteria.

\section{Materials and methods}

\section{Cultivation of bacteria}

Aeromonas hydrophila strains $\mathrm{AH}-1 \mathrm{~N}$ and $\mathrm{AH}-1 \mathrm{~N}$ ahyI (Lynch et al. 2002), Cytophaga sp. strain 4D9 (gene bank accession number EF395377), and all bacterial colonies from enrichments (see below) were cultivated with a HEPES-buffered complex medium designated medium B. Medium B contained the following ingredients (final concentrations): tryptone $(0.05 \%)$, yeast extract $(0.0005 \%)$, HEPES $(10 \mathrm{mM}), \mathrm{NH}_{4} \mathrm{Cl}(5 \mathrm{mM}), \mathrm{MgSO}_{4}(0.5 \mathrm{mM}), \mathrm{KCl}$ $(14 \mathrm{mM})$, and $\mathrm{NaCl}(7.2 \mathrm{mM})$. The $\mathrm{pH}$ was adjusted to 7.0 with $\mathrm{NaOH}$. After autoclaving the medium was complemented with $\mathrm{CaCl}_{2} \quad(0.01 \mathrm{mM})$, phosphate solution $\left(0.15 \mathrm{mM}, \mathrm{pH} 7\right.$, prepared with $\mathrm{K}_{2} \mathrm{HPO}_{4}(0.105 \mathrm{mM})$ and $\mathrm{NaH}_{2} \mathrm{PO}_{4}(0.045 \mathrm{mM})$, and trace element solution SL 10 (Widdel et al. 1983). Chromobacterium violaceum strain CV026 (McClean et al. 1997) and the Escherichia coli strains pSB401, pSB536, and pSB1075 (Winson et al. 1998) were cultivated on Luria-Bertani (LB) medium containing tryptone $(1 \%)$, yeast extract $(0.5 \%)$, and $\mathrm{NaCl}(1 \%)$. Solid media were prepared with $1.5 \%$ Bacto agar (Difco).

Lake water microcosms for enrichment of heterotrophic bacteria

Lake water microcosms were set up with water samples from the littoral zone of Lake Constance and agarose beads containing autoclaved cells of the unicellular green algae Scenedesmus obliquus as nutrient source. The employment of agarose beads was adapted from a study in which they were used to monitor surface attachment of aquatic bacteria (Grossart et al. 2003). Lake water samples were taken with sterile plastic tubes from a pier $10 \mathrm{~m}$ offshore the Limnology Institute (University of Constance) at a depth of about $40 \mathrm{~cm}$ and directly used for enrichments. For preparation of the agarose beads, $50 \mathrm{ml}$ of $S$. obliquus cultures (kindly provided by E. von Elert) with a total carbon content of $12.6 \mathrm{mg}$ were harvested by centrifugation at $10,000 \times \mathrm{g}$ for $10 \mathrm{~min}$ at room temperature, washed with $0.9 \% \mathrm{NaCl}$, and finally resuspended in $4 \mathrm{ml} 0.9 \% \mathrm{NaCl}$ and $16 \mathrm{ml}$ of distilled water. These $20-\mathrm{ml}$ suspensions were supplied with $1 \%$ agarose (Seakem LE agarose, BMA), autoclaved for $20 \mathrm{~min}$ at $121^{\circ} \mathrm{C}$, and poured into Petri dishes $(8.5 \mathrm{~cm}$ diameter). From solidified algae-containing agarose, beads with a total algal carbon content of about $0.06 \mathrm{mg}$ were punched out with a truncated $1 \mathrm{ml}$ pipette tip and placed into $7.5 \mathrm{ml}$ lake water in a sterile glass tube. These tubes were incubated at $16^{\circ} \mathrm{C}$ on a rotatory mixer (CVM, Fröbel) at $100 \mathrm{rpm}$. After $0,24,48$, and $72 \mathrm{~h}$ samples of the lake water (suspended fraction) and whole agarose beads (biofilm fraction) were taken to determine total cell numbers in the suspended fraction and viable cell numbers in both fractions. To determine the total cell counts (TCCs), cells from the suspended fraction were collected on a black polycarbonate filter (pore size $0.2 \mu \mathrm{m}$; Millipore) and stained with $1 \mu \mathrm{g} \mathrm{ml}^{-1}$ DAPI (4', 6-diamidino-2-phenylindole). Cells on filters were counted with epifluorescence microscopy. To 
obtain the biofilm fraction, single agarose beads were repeatedly washed in $0.4 \mathrm{ml}$ medium $\mathrm{B}$. Washed beads were gently homogenized with a sterile plastic pestle in $100 \mu 1$ of potassium phosphate buffer $(50 \mathrm{mM}, \mathrm{pH} 6)$. Homogenates of single beads were further disintegrated enzymatically with 50 units of Pseudomonas atlantica agarase (Sigma) at $30^{\circ} \mathrm{C}$ for $90 \mathrm{~min}$. Viable cells in suspended, washing, and biofilm fractions were quantified by counting colony forming units (CFUs) on medium B agar-plates as described earlier (Klebensberger et al. 2006). Colonies were counted after $24 \mathrm{~h}$ incubation at $16^{\circ} \mathrm{C}$. TCCs of the biofilm fraction could not be determined because it contained many cell clusters and autofluorescing fragments of algae that interfered with DAPI analysis. Microcosm enrichments were set up on June 25,2004 (water temperature $14.5^{\circ} \mathrm{C}$ ), and on November $29,2004\left(8^{\circ} \mathrm{C}\right)$. As controls, microcosms containing beads without algae were employed.

Lake water microcosms for growth experiments with pure strains in single and co-cultures

Lake water samples were taken as described above and sterilized by filtration through a $0.2 \mu \mathrm{M}$ pore membrane (FP30/0.2 CA-S; Schleicher and Schuell). Algae-containing agarose beads were prepared as described above except that the algal carbon content was increased to $0.12 \mathrm{mg}$. Precultures of $A$. hydrophila strains $\mathrm{AH}-1 \mathrm{~N}$ and $\mathrm{AH}-1 \mathrm{~N}$ ahyI and of Cytophaga sp. strain 4D9 were grown with medium $\mathrm{B}$ overnight. TCCs of the pre-cultures were determined as described above. Microcosms containing one agarose bead in $5 \mathrm{ml}$ sterile lake water were inoculated with $10^{6}$ cells ml $\mathrm{ml}^{-1}$ as single or as co-cultures and incubated as described above. After 24,48 , and $72 \mathrm{~h}$ samples from suspended and biofilm fractions were taken and processed as described above. For CFU determination cells were plated on solid medium B with increased tryptone concentration (1\%). After overnight incubation, strain 4D9 and the Aeromonas strains could be unambiguously differentiated by their different colony morphologies since Aeromonas colonies were larger and whitish while Cytophaga colonies were smaller and yellow. The Aeromonas strains AH-1N and $\mathrm{AH}-1 \mathrm{~N}$ ahyI were distinguished by the $C$. violaceum CV026 AHL-bioassay (see below).

\section{Bioassays for AHL-production}

Single colonies obtained from high dilution steps of the CFU counts of the microcosm experiments were transferred to medium B backup plates for systematic storage. All colonies grown on these backup plates were tested for AHL production in bioassays with $C$. violaceum strain CV026 (McClean et al. 1997) and the bioluminescent E. coli strains pSB401, pSB536, and pSB1075 (Winson et al.
1998; Yates et al. 2002). Bioassays with strain CV026 indicating AHLs with short acyl side chains such as $N$-hexanoyl-L-homoserine lactone (HHL) or $N$-octanoyl-Lhomoserine lactone (OHL) were performed by streaking test colonies adjacent to the indicator strain on solid LB medium. AHL-producing bacteria were indicated by violacein production in strain CV026 as described earlier (McClean et al. 1997). The $E$. coli indicator strains respond to different AHLs by producing bioluminescence; strain pSB401 detects AHLs with short and long acyl side chains, strain pSB536 is specific for butanoyl-L-homoserine lactone (BHL), and strain pSB1075 is specific for AHLs with long acyl side chains such as $\mathrm{N}$-3-oxododecanoyl-L-homoserine lactone (OdDHL). For bioassays with the $E$. coli AHL indicator strains, liquid cultures of test colonies were set up with $200 \mu 1$ medium B in 96-well microtiter plates (Microwell, Nunc). After incubation for $48 \mathrm{~h}$ at $16^{\circ} \mathrm{C}$, these microtiter plates were centrifuged at $1,700 \mathrm{~g}$ for $15 \mathrm{~min}$ (5804 R centrifuge with A-2-DWP rotor; Eppendorf). Culture supernatants $(50 \mu \mathrm{l})$ from each well were transferred to black 96-well microtiter plates (Microwell optical bottom plates, Nunc) and supplied with $150 \mu 1$ of E. coli cultures adjusted to an optical density of 0.2 at $600 \mathrm{~nm}$. After 2, 4 and $6 \mathrm{~h}$, bioluminescence and the optical density at $595 \mathrm{~nm}$ were measured with a microtiter plate reader (Genios, Tecan). Bioluminescence intensities were normalized to cell densities of the indicator strains. On each black microtiter plate, positive controls were set up with $0.1 \mu \mathrm{M}$ (final concentration) of either BHL (Fluka), HHL (Fluka), or OdDHL (kindly provided by Paul Williams) for the respective indicator strains. Equivalent volumes of acetonitrile (the solvent for all AHLs) served as negative controls. Extraction of AHLs from culture supernatants and AHL bioassays after separating extracts by thin layer chromatography (TLC) were performed as described earlier (Yates et al. 2002). As lactone rings in AHLs with short acyl side chains tend to hydrolyze at the slightly alkaline $\mathrm{pH}$ values (7.5-8.0) prevailing in the microcosms, we had acidified supernatant samples prior to extraction to reform potentially hydrolyzed lactone rings as described earlier (Yates et al. 2002).

\section{Identification of bacteria}

$\mathrm{N}$-acylhomoserine lactone-positive colonies were purified by transferring single colonies on solid medium B several times. Strains still producing AHLs after purification were further characterized by standard phenotypic assays (Gramtyping, oxidase test) and by $M s p$ I restriction fragment length polymorphism (RFLP) analysis of the 16S rRNA gene PCR product as described earlier (Schmitt-Wagner et al. 2003). Selected strains with distinct RFLP patterns were further identified by sequencing the $16 \mathrm{~S}$ rRNA gene. 
Sequences were compared with the NCBI-database (http:// www.ncbi.com) using the BLAST search tool (Altschul et al. 1997).

\section{Results}

Enrichment of heterotrophic bacteria in lake water microcosms

For enrichment of particle-associated heterotrophic bacteria from the littoral zone of Lake Constance, the natural microflora was exposed to artificial organic particles consisting of autoclaved cells of the naturally occurring alga Scendedesmus obliquus embedded in agarose. In these enrichments, growth of suspended and of particle-associated bacteria (biofilm fraction) was monitored over time. TCCs and CFUs of suspended bacteria increased in all microcosms, and the highest numbers of cells were obtained in microcosms containing agarose beads with algae (Fig. 1a, b). Cultivation efficiencies (CFU/TCC) of suspended bacteria peaked after $48 \mathrm{~h}$ incubation in microcosms with algaecontaining agarose beads and reached values above $60 \%$. In control microcosms containing agarose beads without algae CFU-counts increased less and cultivation efficiencies were around $1 \%$ throughout the experiments. The cultivation efficiency in lake water microcosms without agarose beads was in the same range (not shown). In the biofilm fractions, CFUs in microcosms with algae-containing agarose beads increased much stronger than those from microcosms containing agarose beads without algae (Fig. 1c). As described under Materials and methods TCCs of the biofilm fraction could not be determined for technical reasons. The determination of CFUs in the washing fractions revealed that loosely attached bacteria could be removed (not shown). In summary, algae-containing agarose beads supported growth of heterotrophic bacteria in suspension and in the biofilm fraction. The growth observed in microcosms without algae was also observed in microcosms without any agarose beads (not shown), indicating that this growth must be based on endogenous nutrients from the lake water. The enrichments set up in June (not shown) and November 2004 (Fig. 1) gave similar results.

Screening for and identification of AHL-producing bacteria

All colonies growing on medium B backup plates were screened for AHL-production. As some colonies did not grow on solid LB medium they could not be tested with the indicator strain CV026. This indicator strain responds to AHLs with short acyl side chains only and has a relatively low sensitivity. To overcome these limitations, we developed a screening method of culture supernatants in 96-well microtiter plates using three highly sensitive bioluminescent $E$. coli indicator strains that cover a broad range of AHLs with different acyl side chains (Fig. 2). This procedure allowed a fast screening of a total number of 905 colonies for AHL-production. We found that 244 colonies stimulated indicator strains. Many AHL-producing colonies activated two or more indicator strains, namely strains
Fig. 1 Lake water microcosms for enrichment of heterotrophic bacteria from the littoral zone of Lake Constance. The microcosms contained agarose beads with algae (filled square) and without algae (open square). a TCCs of the suspended fraction, b CFUs of the suspended and $\mathbf{c}$ the biofilm fraction. $d$ Estimated CFUs of AHL-producing bacteria in the suspended fraction ( $A$, $B)$ and the biofilm fraction $(C$, $D$ ) of microcosms containing agarose beads without (open bars) and with algae (filled bars). Microcosms were set up in November 2004. Bars represent standard deviation $(n=6)$
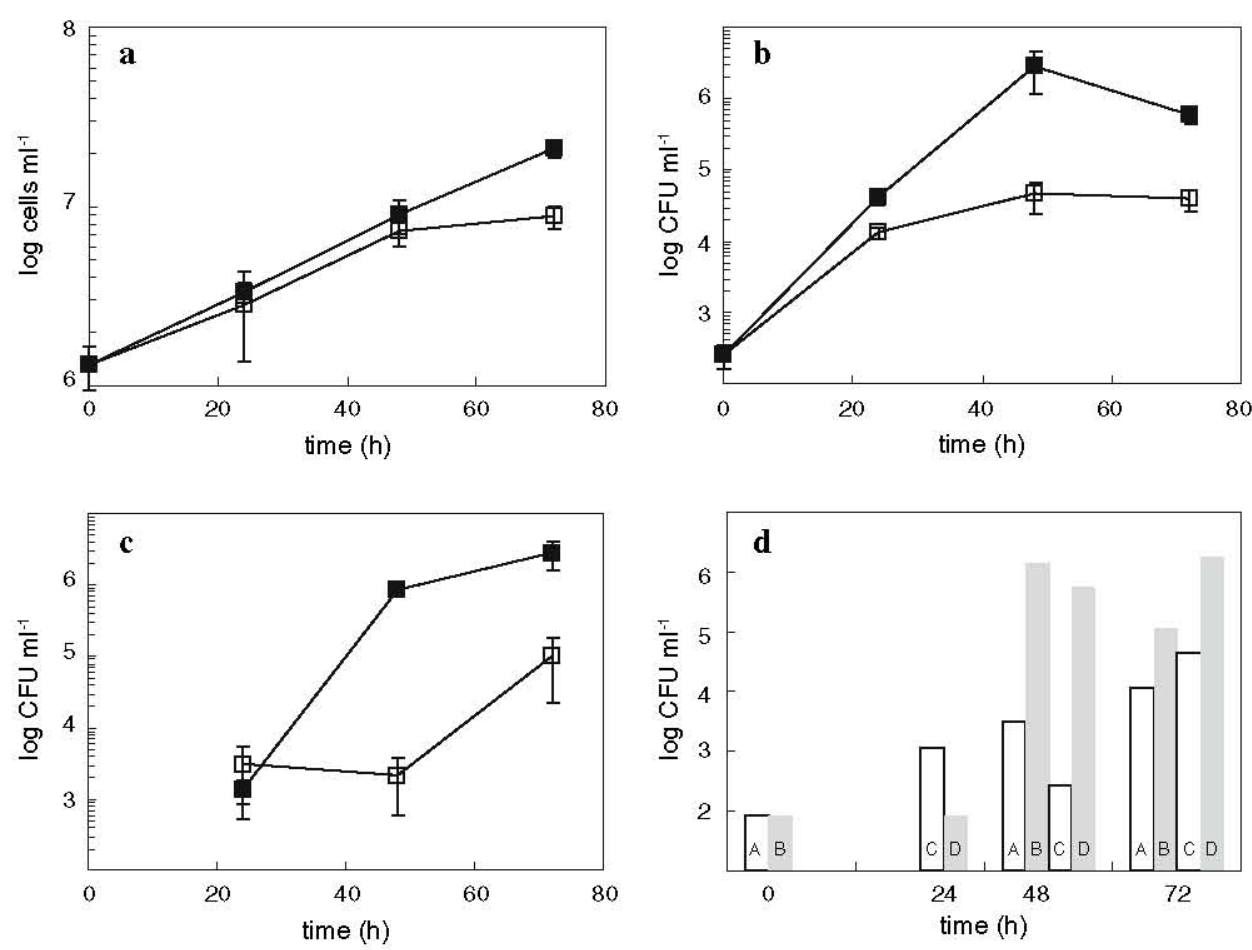


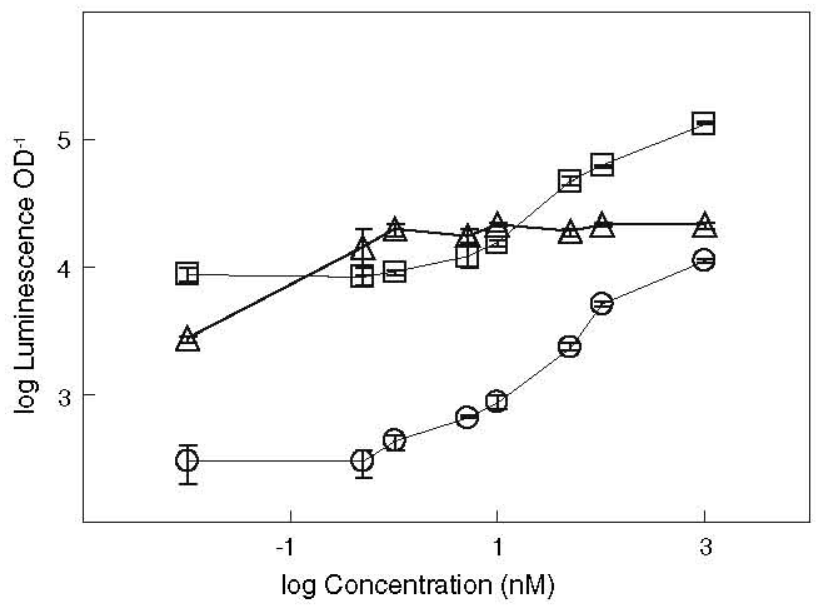

Fig. 2 Response of bioluminescent Escherichia coli indicator strains to different AHL-concentrations after an incubation time of $4 \mathrm{~h}$ : (open square) strain pSB 401 with HHL, (open circle) strain pSB 536 with $\mathrm{BHL}$, (open triangle) strain pSB 1075 with OdDHL. Bars represent standard deviation $(n=3)$

CV026 and pSB536 or strains pSB401 and pSB1075. There were no clear correlations between the origin of colonies (regarding incubation time of and localization within microcosms) and their activation of indicator strains.

The percentages of AHL-producing colonies from total CFUs were determined and used to estimate the total numbers of AHL-producing CFU (Fig. 1d). In all microcosms, AHL-producing bacteria enriched over time. The highest numbers were observed in microcosms with algae-containing agarose beads. After $48 \mathrm{~h}$, there were more than $10^{6}$ AHL-producing colonies $\mathrm{ml}^{-1}$ in the suspended fraction of these microcosms, corresponding to a $10^{4}$-fold enrichment compared to freshly collected lake water. Considering the TCCs, cultivable AHL-producing bacteria accounted for about $15 \%$ of the total bacterial number. To investigate whether the enrichment of AHL-producing bacteria was reflected by the accumulation of AHLs we analyzed supernatants of lake water microcosms with the bioluminescent E. coli strains. AHLs could not be detected in any of the microcosm supernatants, not even in $100 \mu \mathrm{l}$ extracts of $50 \mathrm{ml}$ lake water microcosms including 20 agarose beads with algae [detection limits: $10 \mathrm{nM}$ for $E$. coli $\mathrm{psB} 401$ and E. coli psB 536, $0.5 \mathrm{nM}$ for E. coli pSB1075 (Fig. 2)].

From 244 AHL-producing colonies, 193 AHL-producing pure cultures were isolated and characterized. All AHLproducing isolates were oxidase-positive, Gram-negative bacteria. RFLP-analysis with $M s p$ I showed very similar patterns for all isolates. Sequencing the $16 \mathrm{~S}$ rRNA gene from selected isolates revealed that all of them belonged to the genus Aeromonas, including A. hydrophila, A. sobria, A. salmonicida, and A. veronii. TLC-analysis of supernatants from selected strains grown with medium B indicated production of different AHLs with short acyl side chains, including BHL, HHL, and OHL (not shown). To investigate whether these Aeromonas strains would produce AHLs in lake water microcosms we cultivated selected Aeromonas strains in filter-sterilized lake water containing agarose beads with algae. No AHLs could be detected in organic extracts of small $(7.5 \mathrm{ml})$ or large $(200 \mathrm{ml})$ lake water microcosms.

Growth experiments in lake water microcosms

To test investigate whether AHL-mediated QS had an important function for growth of Aeromonas sp. with organic aggregates, we submitted $A$. hydrophila strain $\mathrm{AH}-$ $1 \mathrm{~N}$ and the AHL-deficient isogenic mutant strain $\mathrm{AH}-1 \mathrm{~N}$ ahyI (Lynch et al. 2002) to growth experiments in lake water microcosms. With these two strains it has been shown previously that AHL-based QS is important for biofilm formation (Lynch et al. 2002) and exoenzyme production (Swift et al. 1999). Thus, these strains were feasible representatives of Aeromonas sp. to test for the function of AHL-mediated QS in our lake water microcosms. In growth experiments with pure Aeromonas cultures, the wild-type strain $\mathrm{AH}-1 \mathrm{~N}$ and the ahyI mutant did not differ regarding growth rates and cell numbers. Both strains reached $10^{7} \mathrm{CFUs} \mathrm{ml} l^{-1}$ in the suspended fraction after $48 \mathrm{~h}$ and about $10^{7} \mathrm{CFUs} \mathrm{ml}{ }^{-1}$ after $72 \mathrm{~h}$ in the biofilm fraction. To investigate whether the wild type had a growth advantage in competition with the ahyI mutant the strains were inoculated at a 1:1 ratio. This ratio remained stable in the suspended and in the biofilm fraction throughout the experiment, indicating that both strains grew equally (Fig. 3a, b). To investigate whether the ahyI mutant might profit from AHL-production by the wild type, the strains were inoculated at a 9:1 ratio of wild type to ahyI mutant. This initial ratio remained also stable throughout growth (not shown). These results indicated that the ability to produce AHLs did not affect growth of $A$. hydrophila strain $\mathrm{AH}-1 \mathrm{~N}$ in lake water microcosms.

To investigate whether cell-cell communication via AHLs might be important for A. hydrophila in competition with other bacteria, we co-inoculated the Aeromonas strains with Cytophaga sp. strain 4D9, which we had isolated from a lake water microcosm. In general, members of the Cytophaga-Flavobacterium group of the Bacteroidetes are abundant in aquatic habitats and are important degraders of polymers (Kirchman 2002; Lemarchand et al. 2006). We isolated several Cytophaga-Flavobacterium strains from high dilution steps of our microcosms. These traits rendered a Cytophaga strain a feasible competitor for $A$. hydrophila in ecophysiological experiments. In pure culture, strain 4D9 grew in the suspended and in the biofilm fraction, reaching higher CFUs than the Aeromonas strains (not shown). If co-inoculated with strains $\mathrm{AH}-1 \mathrm{~N}$ or $\mathrm{AH}-$ $1 \mathrm{~N}$ ahyI individually, strain 4D9 grew like the pure culture 
Fig. 3 Growth of pure strains in defined co-cultures in lake water microcosms. CFUs of a co-culture of Aeromonas hydrophila strains AH-1N (filled square) and ahyI (open square) in (a) suspended and (b) biofilm fractions. CFUs of co-cultures of Cytophaga strain 4D9 (filled circle) with strain $\mathrm{AH}-1 \mathrm{~N}$ (filled square) and of strain 4D9 (open circle) with strain ahyI (open square) in (c) suspended and (d) biofilm fractions. Bars represent standard deviation $(n=9)$
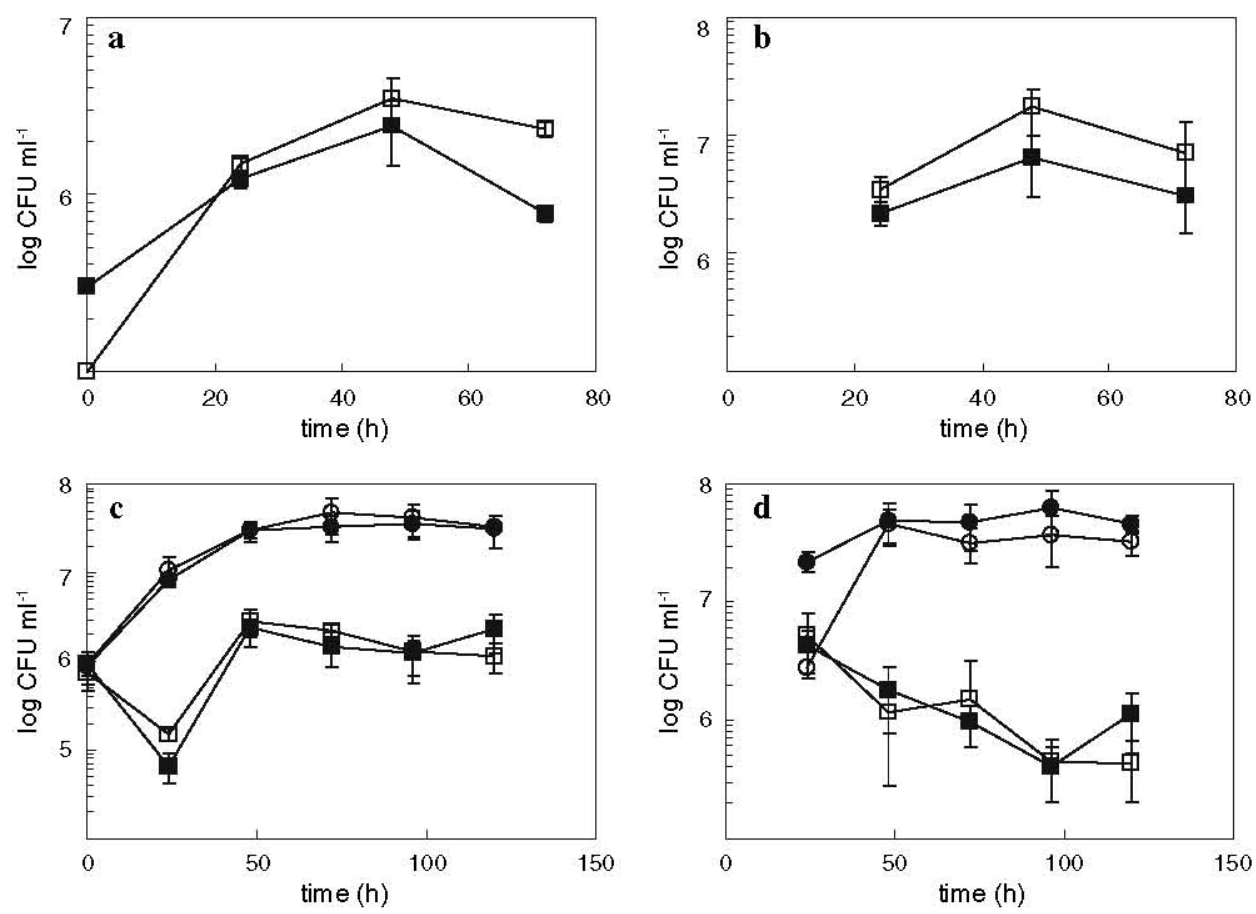

(Fig. 3c, d). The same result was obtained if strain 4D9 was co-inoculated with a 1:1 mixture of strains $\mathrm{AH}-1 \mathrm{~N}$ and $\mathrm{AH}-$ $1 \mathrm{~N}$ ahyI (not shown). These results indicated that growth of Cytophaga strain 4D9 was not influenced by the Aeromonas strains. In contrast, growth of the Aeromonas strains was severely influenced by strain 4D9. Both strains showed only poor growth in co-cultures with strain 4D9 (Fig. 3c, d). In suspended fractions, CFUs of both Aeromonas strains first decreased after $24 \mathrm{~h}$ and then increased to the initial values which remained stable for the remaining incubation time (Fig. 3c). In the biofilm fractions, CFU counts of both Aeromonas strains decreased with time by one order of magnitude (Fig. 3d). No difference between the wild type and the ahyI mutant could be observed.

We could not detect AHLs in any microcosm containing strain AH-1N. To investigate whether the addition of AHLs would influence growth of the Aeromonas strains, we supplied lake water microcosms with BHL $(1 \mu \mathrm{M})$, the cognate AHL of A. hydrophila strain AH1-N. This addition had no effect on growth of strains AH-1N, AH-1N ahyI, and 4D9, neither in pure nor in mixed cultures (not shown). Monitoring BHL in supernatants with $E$. coli pSB536 revealed that the concentration of BHL decreased with time in all lake water microcosms including the sterile control, presumably due to chemical hydrolysis of the lactone ring.

\section{Discussion}

Quorum sensing via AHLs has been shown to be involved in biofilm formation (Kjelleberg and Molin 2002) and competitive or cooperative bacterial interactions (Keller and Surette 2006) in many Gram-negative bacteria. In this study, we scrutinized whether AHL-producing bacteria from oligotrophic lake water would enrich at or in vicinity of organic particles and, if so, whether a potential function of AHL-signaling could be demonstrated in ecophysiological experiments with pure strains in single or defined cocultures. As a prerequisite for these investigations we had to establish lake water microcosms with artificial organic particles which should provide conditions that are very similar to the natural situation in the littoral and that should allow retrieval of particle-associated biofilm bacteria in a reproducible way. The agarose beads containing Scenedesmus obliquus cells met these requirements. While the algal cells served as a nutrient source with a defined carbon concentration for growth of heterotrophic bacteria, the agarose beads themselves were not degraded during the incubation period and served as a mere matrix for algal detritus. The number of bacteria in the suspended fraction of algae-containing microcosms did not exceed cell numbers usually prevailing during algal blooms in Lake Constance (Güde et al. 1985), indicating that the carbon concentration of $S$. obliquus was set in a realistic range. Furthermore, the agarose beads could be disintegrated under comparably mild and defined conditions, allowing qualitative retrieval of particle-associated biofilm bacteria. A second important prerequisite for our study was the establishment of a method that allowed fast screening of a large number of bacteria for AHL-production. The bioassays with highly sensitive Escherichia coli indicator strains in 96-well format proved to be a reliable and efficient screening that 
covered AHLs of different structures and allowed analysis of bacteria that did not grow on solid LB medium.

We found that Aeromonas sp. with the ability to produce AHLs enriched in the biofilm and in the suspended fraction of lake water microcosms with algae-containing agarose beads. These Gammaproteobacteria are ubiquitous in aquatic environments from which they can be readily isolated (von Graevenitz 1987). They occur at low numbers of $10-10^{3} \mathrm{CFU} \mathrm{ml}^{-1}$ in surface waters and show comparably low survival rates in oligotrophic waters (Hazen et al. 1978; Kersters et al. 1996). Although fast-growing Gammaproteobacteria are usually not abundant in natural aquatic systems it has been repeatedly observed that they can transiently enrich at patches of high nutrient availability (Pernthaler and Amann 2005). In agreement with this observation, we showed that cell numbers of Aeromonas strains increased to $10^{6} \mathrm{CFU} \mathrm{ml}^{-1}$ at nutrient hot spots in oligotrophic lake water microcosms. As some Aeromonas species are pathogenic for fish (Bruhn et al. 2005) and for humans (Leclerc et al. 2002; von Graevenitz 2007) our study calls attention to detritus particles as potential reservoirs of these opportunistic pathogens.

At first sight, the enrichment of Aeromonas strains with the ability to form AHLs suggested an important role of AHL-mediated QS for these strains during colonization and degradation of organic particles, thereby supporting our initial hypothesis. However, we could not detect AHLs in any microcosm, not even in 500-fold concentrated extracts, indicating that the natural microflora did not produce significant amounts of AHLs. Nevertheless, AHL-signaling could operate in microcompartments on the organic particles. Diffusion sensing (Redfield 2002) and compartment sensing (Koerber et al. 2005) are modified concepts of QS in which cell-cell communication could occur at low cell numbers if these cells reside in a habitat of low diffusion or if they are clustered in aggregates. A feasible approach to test these alternative concepts of AHL-mediated QS in the lake water microcosms was to compare pure cultures of an AHL-producing Aeromonas strain with an isogenic AHLdefective mutant. AHL-mediated diffusion sensing or compartment sensing should be indicated by reduced growth of the AHL-deficient mutant strain ahyI in the biofilm fraction. However, we did not obtain any evidence of such a growth disadvantage of the ahyI mutant, neither in pure culture nor in competition with the wild type or with Cytophaga sp. strain 4D9. Alternatively, the ahyI mutant could have a growth advantage during co-incubation with the wild type because it could profit from the AHL-signal while avoiding energy investment for its synthesis. A selective advantage of such so-called cheaters has been postulated for QS-deficient mutants (Kreft 2005; Keller and Surette 2006). However, the ahyI mutant had no growth advantage under conditions prone to cheating. As the ahyI mutant had no phenotype in any microcosm experiment and as the addition of BHL to microcosm experiments had no effects, we conclude that AHL-mediated QS is not required for growth of A. hydrophila with organic particles in microcosms simulating the conditions in the littoral of Lake Constance. It must be emphasized that AHL-based cell-cell communication below the detection limit of our indicator strains might occur in microcolonies but it cannot be a prerequisite for growth in this environment. To our knowledge, this is the first systematic attempt to explore the role of AHL-mediated QS for degradation of detritus particles under oligotrophic conditions.

As pointed out in the introduction, the utilization of organic particles by heterotrophic bacteria in aquatic systems is highly prone to involve QS. Why $\operatorname{did} A$. hydrophila not employ AHL-mediated QS although it is undoubtedly required for the production of extracellular enzymes (Swift et al. 1999; Bi et al. 2007) and for biofilm formation (Lynch et al. 2002)? In the respective experiments, A. hydrophila was cultivated in rich media. As AHLs are widespread signal molecules among bacteria of different species their usage implies risks for the producers, such as the aforementioned cheating, unw anted activation of competitors, or signal inactivation by AHL-degrading bacteria (Kreft 2005). Under the nutrient- and energy-limited conditions prevailing in our microcosm experiments, energy investment into QS via such unspecific signals may not pay off. AHL-based signaling may be more important in nutrient-rich environments. In agreement with this assumption AHLs could be extracted from infected fish (Bruhn et al. 2005) and the addition of AHLs to activated sludge had an influence on the bacterial community composition (Valle et al. 2004).

In conclusion, our study reveals that AHLs are not universal signal molecules that bacteria would employ under all environmental conditions, thereby endorsing the search for novel bacterial signal molecules.

Acknowledgments We acknowledge Miguel Cámara and Paul Williams (Nottingham) for gift of the AHL indicator strains, the Aeromonas hydrophila strains, and of OdDHL. We thank Elisabeth Gross for discussions and Bernhard Schink for continuous support. This work was funded by the German Science Foundation (DFG) in the Collaborative Research Center SFB454, project B9, to B.P..

\section{References}

Altschul SF, Madden TL, Schaffer AA, Zhang J, Zhang Z, Miller W, Lipman DJ (1997) Gapped BLAST and PSI-BLAST: a new generation of protein database search programs. Nucleic Acids Res 25:3389-3402

Azam F, Long RA (2001) Sea snow microcosms. Nature 414:495, $497-498$

Azam F, Smith DC, Steward GF, Hagström $\AA$ (1993) Bacteria-organic matter coupling and its significance for oceanic carbon cycling. Microb Ecol 28:167-179 
Bi ZX, Liu YJ, Lu CP (2007) Contribution of AhyR to virulence of Aeromonas hydrophila J-1. Res Vet Sci. doi:10.1016/ j.rvsc. 2007.01 .003

Bruhn JB, Dalsgaard I, Nielsen KF, Buchholtz C, Larsen JL, Gram L (2005) Quorum sensing signal molecules (acylated homoserine lactones) in gram-negative fish pathogenic bacteria. Dis Aquat Organ 65:43-52

Bruns A, Cypionka H, Overmann J (2002) Cyclic AMP and acyl homoserine lactones increase the cultivation efficiency of heterotrophic bacteria from the central Baltic Sea. Appl Environ Microbiol 68:3978-3987

Bussmann I, Philipp B, Schink B (2001) Factors influencing the cultivability of lake water bacteria. J Microbiol Methods 47:41-50

Chhabra SR, Philipp B, Eberl L, Givskov M, Williams P, Cámara M (2005) Extracellular communication in bacteria. In: Schulz S (eds) Topics in current chemistry. Springer GmbH, pp 279-315

Gram L, Grossart HP, Schlingloff A, Kiørboe T (2002) Possible quorum sensing in marine snow bacteria: production of acylated homoserine lactones by Roseobacter strains isolated from marine snow. Appl Environ Microbiol 68:4111-4116

Grossart HP, Kiørboe T, Tang K, Ploug H (2003) Bacterial colonization of particles: growth and interactions. Appl Environ Microbiol 69:3500-3509

Güde H, Haibel B, Müller H (1985) Development of planctonic bacterial populations in a water column of Lake Constance (BodenseeObersee). Arch Hydrobiol 105:59-77

Hanisch K, Schweitzer B, Simon M (1996) Use of dissolved carbohydrates by planktonic bacteria in a mesotrophic lake. Microb Ecol 31:41-55

Hazen TC, Fliermans CB, Hirsch RP, Esch GW (1978) Prevalence and distribution of Aeromonas hydrophila in the United States. Appl Environ Microbiol 36:731-738

Joint I, Tait K, Callow ME, Callow JA, Milton D, Williams P, Cámara $\mathrm{M}$ (2002) Cell-to-cell communication across the prokaryoteeukaryote boundary. Science 298:1207

Keller L, Surette MG (2006) Communication in bacteria: an ecological and evolutionary perspective. Nat Rev Microbiol 4:249-258

Kersters I, Huys G, Van Duffel H, Vancanneyt M, Kersters K, Verstraete W (1996) Survival potential of Aeromonas hydrophila in freshwaters and nutrient-poor waters in comparison with other bacteria. J Appl Bacteriol 80:266-276

Kiørboe T, Jackson GA (2001) Marine snow, organic solute plumes, and optimal chemosensory behavior of bacteria. Limnol Oceanogr 46:1309-1318

Kirchman DL (2002) The ecology of Cytophaga-Flavobacteria in aquatic environments. FEMS Microbiol Ecol 39:91-100

Kjelleberg S, Molin S (2002) Is there a role for quorum sensing signals in bacterial biofilms? Curr Opin Microbiol 5:254-258

Klebensberger J, Rui O, Fritz E, Schink B, Philipp B (2006) Cell aggregation of Pseudomonas aeruginosa strain $\mathrm{PAOl}$ as an energy-dependent stress response during growth with sodium dodecyl sulfate. Arch Microbiol 185:417-427

Koerber AJ, King JR, Williams P (2005) Deterministic and stochastic modelling of endosome escape by Staphylococcus aureus: "quorum" sensing by a single bacterium. J Math Biol 50:440-488

Kreft J-U (2005) Conflicts of interest in biofilms. Biofilms 1:265-276

Leclerc H, Schwartzbrod L, Dei-Cas E (2002) Microbial agents associated with waterborne diseases. Crit Rev Microbiol 28:371-409

Lemarchand C, Jardillier L, Carrias JF, Richardot M, Debroas D, Sime-Ngando T, Amblard C (2006) Community composition and activity of prokaryotes associated to detrital particles in two contrasting lake ecosystems. FEMS Microbiol Ecol 57:442-451
Long RA, Rowley DC, Zamora E, Liu J, Bartlett DH, Azam F (2005) Antagonistic interactions among marine bacteria impede the proliferation of Vibrio cholerae. Appl Environ Microbiol 71:85318536

Lynch MJ, Swift S, Kirke DF, Keevil CW, Dodd CE, Williams P (2002) The regulation of biofilm development by quorum sensing in Aeromonas hydrophila. Environ Microbiol 4:18-28

Manefield M, Turner SL (2002) Quorum sensing in context: out of molecular biology and into microbial ecology. Microbiology $148: 3762-3764$

McClean KH, Winson MK, Fish L, Taylor A, Chhabra SR, Cámara M, Daykin M, Lamb JH, Swift S, Bycroft BW, Stewart GS, Williams $P$ (1997) Quorum sensing and Chromobacterium violaceum: exploitation of violacein production and inhibition for the detection of $N$-acylhomoserine lactones. Microbiology 143:3703-3711

McLean RJ, Whiteley M, Stickler DJ, Fuqua WC (1997) Evidence of autoinducer activity in naturally occurring biofilms. FEMS Microbiol Lett 154:259-263

Pernthaler J, Amann R (2005) Fate of heterotrophic microbes in pelagic habitats: focus on populations. Microbiol Mol Biol Rev 69:440-461

Redfield RJ (2002) Is quorum sensing a side effect of diffusion sensing? Trends Microbiol 10:365-370

Schmitt-Wagner D, Friedrich MW, Wagner B, Brune A (2003) Phylogenetic diversity, abundance, and axial distribution of bacteria in the intestinal tract of two soil-feeding termites (Cubitermes spp.). Appl Environ Microbiol 69:6007-6017

Simon M, Grossart HP, Schweitzer B, Ploug H (2002) Microbial ecology of organic aggregates in aquatic ecosystems. Aquat Microb Ecol 28:175-211

Swift S, Lynch MJ, Fish L, Kirke DF, Tomas JM, Stewart GS, Williams P (1999) Quorum sensing-dependent regulation and blockade of exoprotease production in Aeromonas hydrophila. Infect Immun 67:5192-5199

Tait K, Joint I, Daykin M, Milton DL, Williams P, Cámara M (2005) Disruption of quorum sensing in seawater abolishes attraction of zoospores of the green alga Ulva to bacterial biofilms. Environ Microbiol 7:229-240

Valle A, Bailey MJ, Whiteley AS, Manefield M (2004) $\mathrm{N}$-acyl-Lhomoserine lactones (AHLs) affect microbial community composition and function in activated sludge. Environ Microbiol 6:424 433

von Graevenitz A (1987) Research on Aeromonas and Plesiomonas. Experientia 43:348-358

von Graevenitz A (2007) The role of Aeromonas in diarrhea: a review. Infection 35:59-64

Waters CM, Bassler BL (2005) Quorum sensing: cell-to-cell communication in bacteria. Annu Rev Cell Dev Biol 21:319-346

Widdel F, Kohring G-W, Mayer F (1983) Studies on dissimilatory sulfate-reducing bacteria that decompose fatty acids. Arch Microbiol $134: 286-294$

Winson MK, Swift S, Fish L, Throup JP, Jørgensen F, Chhabra SR, Bycroft BW, Williams P, Stewart GS (1998) Construction and analysis of $l u x C D A B E$-based plasmid sensors for investigating $N$ acyl homoserine lactone-mediated quorum sensing. FEMS Microbiol Lett 163:185-192

Yates EA, Philipp B, Buckley C, Atkinson S, Chhabra SR, Sockett RE, Goldner M, Dessaux Y, Cámara M, Smith H, Williams P (2002) $\mathrm{N}$-acylhomoserine lactones undergo lactonolysis in a $\mathrm{pH}-$, temperature-, and acyl chain length-dependent manner during growth of Yersinia pseudotuberculosis and Pseudomonas aeruginosa. Infect Immun 70:5635-5646 